\title{
In the balance: weighing up the effects of risk taking on sustainability
}

Risk taking is clearly a significant element of entrepreneurial activity. Some would argue that the preparedness to take risks is one of the defining personal traits of an entrepreneur. Risk taking, though, is a complex concept in itself and the motivations which lead firms to take risks may also vary. When the stakes are high and the dynamics are not what they should be things can go spectacularly wrong with negative impacts not only on the firm and its employees but also on the wider society. Many countries still feel the effects of the financial crisis of a decade ago - a crisis which has impacted not only firms but whole nations as they have taken austerity measures to put their economies back on track.

Sustainability is another issue which is absolutely central to business as firms look to demonstrate real consideration not just for profit but also for their various internal and external stakeholders, wider society and the planet itself: How are scarce resources used? How responsible is the firm in dealing with its waste? How does it deal with aspects such as equality amongst the workforce? The list goes on.

\section{The study}

Younas and Zafar (2019) point out that while there has been a fair amount of research into the influence of sustainability on risk taking, there has been little in terms of the effects of risk taking on sustainability. This is something they set out to address in their study of manufacturing and utility firms in the USA and Germany over the years 2004-2015. They wanted to shed more light on this important area for decision makers.

Germany and the USA represented interesting focal points for the research in this area. The former country has a particularly firm board oversight - with boards functioning on two levels and featuring independence as part of their make-up - to provide control on decision making. The USA has the Sarbanes-Oxley Act which was passed at the beginning of this century with the goal of mitigating the taking of excessive and unhealthy risk. In their study, the authors considered numerous aspects of the firms including elements such as size and growth as well as aspects such as the make-up of the board and return on assets.

Younas and Zafar consider the motivations of those taking risks. They report the literature questioning whether aspects such as career development might in some circumstances play a stronger role than it should with the best interests of the firm and its stakeholders taking a comparative back-seat. In the same vein, confidence rather than caution may be qualities such managers wish to display - potentially leading to the wrong sorts of decision being taken.

They also point out that risk-taking behavior is demanding of resources and requires shifts that favor shareholders - i.e. those with a financial investment in the company - at the expense of other stakeholders - i.e. those who would benefit from the pursuit of sustainability (employees and society at large, for example).

That said, in reviewing the literature they also report that the taking of risks builds value - when accompanied by solid oversight from effective structures both within the firm and within the wider regulatory environment in which it operates.

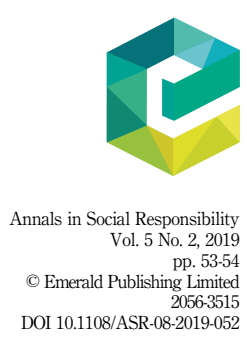


ASR

5,2

In approaching this subject the authors set out to answer two questions:

(1) What influence does the size and levels of independence of the board play in ensuring healthy risk decisions?

(2) What effect does risk-taking behavior have on sustainability?

\section{Findings}

So what did they discover? In terms of the two countries covered they found that German firms demonstrate the higher levels of sustainability whilst the US ones tend to take higher risks than their German counterparts. The German companies tend to feature boards which are greater in size and levels of independence. Generally speaking, the risks being taken in both countries could be regarded as reasonable.

They also found a reduction in sustainability amongst companies when level of risk taking was on the rise. The authors attribute this to the process by which resources are reallocated from areas that benefit the wider stakeholders - for example, employees and society in general - into areas that have specific benefit to shareholders.

Furthermore, strong board oversight served to limit excesses in terms of behavior in the area of risk taking.

\section{Implications}

What are the implications for organizations as they take decisions involving risk? CSR has huge and increasing importance for organizations as we move towards the third decade of our century. Risk taking is always going to be a part of business but an awareness of the effects each decision will have on sustainability is surely something demanding consideration.

Moreover, effective oversight on decision making is likely to limit the damages caused within and without the firm by excessively risky behavior - sometimes motivated more by personal success than that of the organization. Business should therefore consider the nature of the oversight they have in play.

There is insight here not only for those taking decisions but also those evaluating them at board level. There is something here for policy makers seeking to ensure a firm regulatory environment in which firms operate. Finally, this research is of value to those preparing for a career in business and their educators. Given our recent history of the financial crisis, a fully rounded view on issues around risk is an essential tool for our managers of tomorrow.

\section{Comment}

The review is based on "Corporate risk taking and sustainability: a case of listed firms from USA and Germany" by Zahid Irhsad Younas and Ameena Zafar (2019).

\section{Reference}

Younas, Z.I. and Zafar, A. (2019), "Corporate risk taking and sustainability: a case of listed firms from USA and Germany", Journal of Global Responsibility, Vol. 10 No. 1, pp. 2-15, available at: https:// doi.org/10.1108/JGR-07-2018-0027 